\section{O cientificismo das teorias raciais em O cortiço e Canã̃}

\section{The scientism of racial theories in $\mathrm{O}$ cortiço and Canaã}

\section{Luana Tieko Omena Tamano}

Mestranda em História Social pela Universidade de São Paulo (USP). R. Nelson Marinho de Araújo, 354/304 57045-570 - Maceió - AL - Brasil

luanatamano@yahoo.com.br

\section{Poliana dos Santos}

Mestre em Letras pela Universidade Federal de Alagoas (Ufal) Av. Alípio Barbosa, 672 57010-810 - Maceió - AL - Brasil

poliana.stos@hotmail.com

\section{Gildo Magalhães}

Professor do Departamento de História/USP. USP - Departamento de História Rua Prof. Lineu Prestes, 368 05508-900 - São Paulo - SP - Brasil

gildomsantos@hotmail.com

Ana Claudia Aymoré Martins

Professora do Departamento de História/Ufal. R. Lourenço Moreira da Silva, 32/703 57035360 - Maceió - AL - Brasil ana_aymoré@hotmail.com

Recebido para publicação em fevereiro de 2009 Aprovado para publicação em maio de 2011
TAMANO, Luana Tieko Omena et al. $\mathrm{O}$ cientificismo das teorias raciais em O cortiço e Canaã. História, Ciências, Saúde - Manguinhos, Rio de Janeiro, v.18, n.3, jul.-set. 2011, p.757-773.

\section{Resumo}

Analisa a introdução das teorias raciais no Brasil e seu acolhimento por intelectuais brasileiros, na virada do século XIX para o XX. Discute a mestiçagem, o racismo e as políticas de branqueamento com base nos romances $O$ cortiço (1890), de Aluísio Azevedo, e Canaã (1902), de Graça Aranha, por considerá-los testemunhas da mentalidade da época. Examina, por meio de análise histórica e literária, como a ficção representa esteticamente o Brasil e o dilema nacional.

Palavras-chave: teorias raciais; mestiçagem; políticas de branqueamento; literatura; Brasil.

\section{Abstract}

This analysis of the introduction of racial theories to Brazil and their reception by Brazilian intellectuals in the late nineteenth/early twentieth centuries looks at miscegenation, racism, and whitening policies through the lenses of two novels that bear witness to the era's mentality: $\mathrm{O}$ cortiço (1890; A Brazilian tenement, 1976), by Aluísio Azevedo, and Canaã (1902; Canaan, 1920), by Graça Aranha. Through historical and literary analysis, the article examines how fiction has portrayed Brazil and the national dilemma aesthetically.

Keywords: racial theories; miscegenation; whitening policies; literature; Brazil. 


\section{Uma ideologia de grande repercussão: o racismo}

Em 1853 surgiu a obra mais conhecida do francês Joseph-Arthur de Gobineau (18161882), Ensaio sobre a desigualdade da raça humana, considerada por seu autor um trabalho de ciências exatas e destinada a ser tão revolucionária quanto a teoria copernicana. A pretensão de cientificidade não foi desmascarada na época, devido a fatores ideológicos ligados sobretudo ao colonialismo europeu e à presença ainda marcante da escravatura. Diferentemente de antropólogos alemães que haviam tratado do tema, para Gobineau a miscigenação era sempre ruim. Inspirado por uma ideologia aristocrática e romântica, afirmava que a degeneração racial decorrente da mistura das três raças então reconhecidas - oriental, negroide e caucasiana - significava a destruição da vitalidade original da raça branca europeia, que denominava arianos em referência à suposta diáspora dos árias, um grupo indo-europeu. Esses ancestrais eram considerados superiores cultural e fisicamente, ligados à terra e a sua nobreza e com as virtudes do isolado selvagem rousseauniano (Herman Jr., 1999, p.63-64).

Ainda de acordo com essa teoria, como efeito do cruzamento inter-racial o sangue ariano foi-se diluindo e caminhando em direção a sua corrupção; este seria um fim triste, mas inevitável para alemães, latinos e gauleses, herdeiros ignorantes e ignóbeis de uma raça outrora imponente (Herman Jr., 1999, p.70). As novas civilizações, em vez de ganharem a vida com a terra e as guerras, aprenderam os ofícios 'vis' do comércio e da era industrial, privando-se da força, da beleza e da inteligência originais. ${ }^{1}$

O determinismo e pessimismo raciais de Gobineau sofreram a crítica de Alexis de Tocqueville (1805-1859), que apontou a insensatez de acreditar que a ação humana seja puro fruto biológico do sangue e da raça, sem espaço para a liberdade e a escolha moral. No entanto, a obra de Gobineau fez grande sucesso na Alemanha, onde toda uma linhagem de intelectuais foi muito influenciada por suas teorias raciais, destacando-se entre eles Richard Wagner (1813-1883) e Friedrich Nietzsche (1844-1900). O círculo de Wagner, em Bayreuth, foi um importante centro de disseminação das ideias gobinianas, influenciando o movimento alemão ultranacionalista que fundou, em 1894, a Sociedade Gobineau. Sob essa liderança difundiu-se a ideologia pangermanista de que os arianos não tinham desaparecido, mas se transformado em teutões nas florestas e brejos da Europa do Norte. O genro de Wagner, Houston Chamberlain (1855-1927), por sua vez, espalhou essas ideias pelo mundo anglófilo e introduziu um novo elemento, ao culpar os judeus pela perda da vitalidade ariana, a quem acusava de serem os maiores corruptores da raça pura.

A conexão de Gobineau com o Brasil é essencial para entender como a ideologia das teorias racistas pode ter sido útil para ajudar o país a conservar a escravidão por tanto tempo. Entre 1869 e 1870, a vida algo rocambolesca de Gobineau levou-o ao Rio de Janeiro como ministro na legação diplomática francesa junto a dom Pedro II (Raeders, 1998). A amizade de Gobineau com o imperador brasileiro prolongou-se mesmo depois de acabada a sua missão oficial e de seu retorno à França, e prosseguiu por meio de volumosa correspondência e encontros no exterior. A permanência do francês em terras tropicais serviu apenas para reforçar suas convicções de que, dado o altíssimo grau de mestiçagem aqui observado, a raça brasileira estava fadada a desaparecer, sucumbindo aos mulatos 
'degenerados e malandros'. Gobineau chegou a calcular o ano desse desenlace infeliz: 2140 d.C. Para ele, era sempre preferível que não houvesse o cruzamento inter-racial, até mesmo para os negros, que, como raça pura, seriam superiores aos descendentes mulatos. Justificavase, assim, que continuasse a haver escravidão no Brasil, pois com a abolição seria muito maior o perigo da mestiçagem.

\section{O contexto das teorias raciais no Brasil}

O século XIX foi decisivo para a história nacional e viveu grandes mudanças nas esferas social, política, econômica, culturais e ideológicas. Como afirmaram Veloso e Madeira (1999, p.59), esse século inaugurou uma nova maneira de pensar e inscrever o país na modernidade ocidental. Além disso, o período foi marcado por contradições ideológicas das elites brasileiras, que ansiavam fazer parte da vida culta e do progresso europeu, porém sem abdicar das riquezas e dos lucros obtidos com o sistema escravocrata. Desse modo, as ideias liberais de igualdade e trabalho livre, discursadas após a Independência, alteravam a antiga ordem política mas não modificavam as estruturas socioeconômicas resultantes da exploração colonial.

As teorias raciais foram criadas no decorrer do século XIX na Europa, momento considerado o ápice do chamado racismo científico. Para Paes (1992, p.161), essas teorias foram as manifestações máximas do chamado darwinismo social. No período, procurouse naturalizar as desigualdades a fim de provar a superioridade branca. Assim, o europeu não chegava a sentir conflito ideológico com seus ideais democráticos e liberais, pois não fora ele que intencionalmente estabelecera as diferenças entre as raças; ao contrário, elas eram determinadas pela natureza (Leite, 2002, p.38).

Quando essas teorias desembarcaram no Brasil, em fins do século XIX, o país ainda era escravista, com forte presença de traços típicos de uma ex-colônia, com economia débil e dependente - baseada em monocultura, latifúndio e exportação de bens primários -, politicamente desestruturado e com infraestrutura urbana deficiente. Em meio a um contexto histórico tão diferente, era preciso saber como aplicar à realidade nacional doutrinas tidas como científicas e vindas do 'continente do progresso'. Foi a diminuta classe intelectual do país que tomou para si a responsabilidade de adequar essas doutrinas ao Brasil. ${ }^{2}$ Os intelectuais brasileiros estudaram-nas, analisaram-nas, refutaram o que não se adequava ao Brasil e retiveram o que era possível aplicar à nossa realidade, no objetivo de construir "um argumento racial no país" (Schwarcz, 2002, p.18). Era cada vez mais premente abolir a escravidão, menos pelos princípios humanitários do que pelo estigma negativo de país escravista no cenário internacional, não obstante o discurso iluminista que aqui se propagou no século XVIII, relativo aos direitos inalienáveis dos homens, à liberdade e à igualdade.

A importação de mão de obra escrava começou no século XVI e perdurou até o XIX. Mais de três milhões de africanos foram trazidos ao Brasil, para trabalhar principalmente nas lavouras. ${ }^{3}$

Com a pressão externa em favor da abolição do tráfico de escravos, sobretudo por parte da Inglaterra (ainda que eivada de hipocrisia e em defesa de seus próprios interesses comerciais), algumas leis foram criadas, mas nenhuma foi efetivamente colocada em prática. 
Além disso, mesmo com o fim do tráfico, em 1850, com a Lei Eusébio de Queiroz, a comercialização interna de escravos continuou, e muitas batalhas foram travadas entre governo, abolicionistas e cafeicultores - no século XIX, o café tornou-se o principal produto da economia brasileira.

Desde a década de 1870 discutia-se a substituição da mão de obra negra pela imigrante, e percebia-se que a abolição era questão de tempo, devido às pressões externas e ao movimento abolicionista em curso no país. Com a abolição da escravidão, colocou-se a questão sobre o que fazer com a grande quantidade de libertos. Os antigos abolicionistas 'desapareceram', pois o que propunham era a libertação dos escravos, e o destino deles era um assunto pessoal de cada um.

Os anos que se seguiram a 1870 foram marcados pela entrada, no país, de uma enxurrada de 'ismos': evolucionismo, abolicionismo, positivismo, anarquismo, liberalismo, determinismo (geográfico), republicanismo. Ideias emergentes em meio a um país sem universidades, cuja tarefa de entendê-las e adequá-las foi delegada à classe intelectual que, no impasse de aceitá-las ou refutá-las, optou, em boa parte, pela 'ressignificação'. Pairava sob essas teorias uma ideia teleológica, no sentido de uma marcha linear em direção à civilização. Intimamente imbricadas entre si, era difícil se querer liberal e continuar escravista, instalar a República sem o pensamento positivista, aceitar o evolucionismo e creditar as afirmações de que éramos atrasados e inferiores, crer que os trópicos inibem o desenvolvimento nacional.

\section{A tessitura republicana e o processo ficcional em Aluísio Azevedo e Graça Aranha}

O regime republicano, em seu início, caracterizou-se por ações violentas contra a população. As perseguições ao jogo do bicho e a guerra às habitações coletivas acarretavam uma imagem negativa do novo sistema político e, por conseguinte, a falta de apoio das camadas mais pobres. No Distrito Federal, a destruição do célebre cortiço Cabeça de Porco durante a administração do prefeito Barata Ribeiro, em 1893, prenunciava investidas da jovem República contra a chamada classe perigosa, isto é, os pobres.

Vários foram os motivos que transformaram os cortiços em alvo predileto do regime republicano, entre eles o fato de se localizarem nos centros das cidades e se tornarem obstáculos às modificações urbanas em curso, especialmente no Rio de Janeiro, capital do país. Além disso, essas residências eram consideradas focos de vícios, pois nelas reinavam hábitos 'imorais' como a ociosidade e o amancebamento. Outra razão seria a noção de que esses lugares eram refúgio de escravos e facilitavam o contágio de doenças, pois neles grassavam a sujeira e a falta de saneamento (Chalhoub, 1996, p.29).

Para políticos e médicos da época, o que estava em jogo, nas demolições aos domicílios populares, era o próprio futuro do país como nação. Era preciso acabar com os focos de contaminação e desregramento que essas residências representavam, tomá-las como um problema de controle social e saúde pública. Para Chalhoub (1996, p.35), a higiene viria a ser uma ideologia de Estado, uma vez que os princípios higienistas, baseados em técnicas próprias e consideradas científicas, eram os condutores das decisões políticas, assim como dos instrumentos para obter o progresso nacional. A população ficou, então, de mãos atadas, pois o imperativo científico justificava todas as maneiras de violência a ela infligida. 
Ressalte-se que o regime republicano, mais do que destruir moradias pobres, promoveu uma verdadeira caça às bruxas em relação a hábitos e tradições do povo. Tudo o que recordava velhos costumes era condenado. Assim, coibiu-se a "venda ambulante de alimentos, o ato de cuspir no chão dos bondes, o comércio de leite em que as vacas eram levadas de porta em porta, a criação de porcos dentro dos limites urbanos, a exposição da carne na porta dos açougues, a perambulação de cães vadios ..." (Needell, 1993, p.57). Do mesmo modo, foi vetado o festejo da malhação do Judas e do bumba meu boi, as festas da Penha (em São Paulo) e da Glória (no Rio de Janeiro) foram cerceadas e o carnaval foi severamente restringido, em especial as fantasias de índios e os cordões (Sevcenko, 2003, p.46-47).

Encorajado pelo estilo parisiense, o prefeito Pereira Passos geriu as mudanças na capital do país, demolindo edifícios coloniais, alargando ruas, construindo avenidas e palacetes, e empurrando a população para os morros e lugares mais distantes do Centro da cidade. O ápice desses novos tempos foi a inauguração, em 1904, da avenida Central, no Centro do Rio de Janeiro. Mais do que uma via urbana, a obra metaforizava a entrada do país no mundo civilizado; era uma ode à modernidade que se vaticinava. As transformações ocorridas na capital logo se tornaram uma metonímia do Brasil: não era apenas o Rio que se civilizava, na concepção elitista da época, mas sim a nação inteira. Cabe observar que, dois meses após a inauguração da avenida, foi deflagrada a Revolta da Vacina, uma das maiores manifestações populares contra o projeto civilizatório incitado pela República. Durante a rebelião, bondes foram queimados, barricadas foram erigidas, o tráfego ficou parado e postes de luz foram destruídos (Carvalho, 1987, p.72).

A República foi erguida com uma grande interrogação, cuja resposta punha em risco o destino de um povo: como alcançar um estado civilizatório nos moldes europeus? Era urgente adiantar os ponteiros do tempo e acelerar o processo de modernização, mas, para uma opulenta minoria, um óbice era evidente: a classe pobre. Nesse sentido, os higienistas viam a população e suas aglomerações como reduto de vícios e moléstias; os defensores das teorias raciais apregoavam o limbo em que habitava o brasileiro, entre o céu e o inferno da mestiçagem; e os proprietários rurais qualificavam as camadas miseráveis inaptas para o trabalho.

Outra dificuldade se colocava, consoante a mentalidade da época, para a construção do Brasil: o clima. Pensava-se que a adaptação ao ambiente quente, sobretudo por estrangeiros, era necessária ao desenvolvimento nacional. Indicavam-se alguns cuidados para evitar os males e incômodos resultantes do calor dos trópicos ao equador. Os imigrantes deviam ingerir alimentos "leves e bem cozidos" e evitar frutas ácidas e bebidas alcoólicas, as roupas deviam ser leves e folgadas, e recomendava-se, ainda, "evitar os excessos venéreos, aos quais tanto excita o ardor do clima" (Chalhoub, 1996, p.85).

Foi nesse turbulento contexto histórico que Aluízio Azevedo (1857-1913) e Graça Aranha (1868-1931) escreveram suas principais obras, O cortiço e Canaã. Imbuídos pelas teorias do período, costuraram seus romances com as linhas cientificistas do naturalismo, em que se cruzam raças, ambientes e ajuntamentos humanos. Crítico ferrenho da sociedade, Azevedo aderiu a uma postura antilusitana, vendo no português o desbravador que vem principalmente para dominar a terra e sugar suas riquezas. Como caricaturista de jornais políticos e humorísticos (O Mequetrefe, Fígaro, Zig-Zag), o escritor pintou suas personagens em tons burlescos 
e jocosos, satirizando a situação social do momento. A mesma atitude crítica em relação aos problemas brasileiros pode ser observada em Aranha. Homem de espírito moderno, via no imigrante alemão o explorador que Azevedo viu no português. De suas viagens como diplomata, trouxe para o Brasil elementos da estética e do pensamento europeus, buscou vivificar a cultura nacional e tornou-se um dos incentivadores da Semana de Arte Moderna de 1922 (Bosi, 2006, p.325).

Perrone-Moisés (1990, p.102) observa: “A literatura parte de um real que pretende dizer, falha sempre ao dizê-lo, mas ao falhar diz outra coisa, desvenda um mundo mais real do que aquele que pretendia dizer". Foi desse modo que os escritores aqui em análise elaboraram suas obras, e ao ter como foco a realidade de seu tempo desfiguraram-na, puseram-na pelo avesso, como só a linguagem simbólica pode fazê-lo.

\section{O cortiço e Canaã como expressões literárias de teorias raciais}

Aluísio Azevedo, assim como Graça Aranha, nasceu em São Luís do Maranhão. Ambos, de famílias abastadas, seguiram a carreira diplomática e literária. Azevedo abraçou a corrente do naturalismo, ao passo que Aranha enveredou pela ficção pré-modernista, embora sejam perceptíveis alguns traços naturalistas em alguns de seus romances, em especial Canaã. Pode-se dizer que, de modos diversos, os dois romancistas trabalharam com temas comuns, tais como as teorias raciais, as ideias deterministas e a política do branqueamento. Pertencentes a um mesmo contexto histórico-cultural, reconstruíram e interpretaram angústias e conflitos dos escritores e intelectuais brasileiros sobre a identidade e o futuro do país e de seu povo. Contudo, foi Aranha quem deu tratamento especial à questão da imigração, em seu livro Canaã.

Azevedo buscou traçar um quadro da sociedade brasileira por meio de uma linguagem cientificista e determinista do homem e dos agrupamentos humanos. Comungando com as concepções de seu tempo, entre elas as teorias positivistas e darwinistas, encontrou na corrente naturalista do século XIX o fundamento para analisar, em seus romances, as instituições e o 'caráter' do povo brasileiro, ora denunciando a hipocrisia, a miséria e a exploração da burguesia contra os pobres, ora justificando esses aspectos por meio do determinismo.

Para naturalistas como Azevedo, o homem é um objeto de estudo e pode ser artisticamente representado de modo fiel à realidade. $\mathrm{O}$ indivíduo é um produto biológico, cuja conduta resulta da imposição do ambiente social e da hereditariedade. Nesse sentido, o romancista assumia uma atitude que se pretendia objetiva, de impessoalidade diante dos problemas sociais ao ressaltar temas como criminalidade, raça, doenças, vícios e desejos sexuais. ${ }^{4}$ Algumas dessas características podem ser notadas em O mulato, de 1881, mas seu ápice é O cortiço, considerado, por muitos críticos, uma obra inspirada em L'assommoir e Germinal, de Zola.

O cortiço se passa no subúrbio da cidade do Rio de Janeiro, no final do século XIX. A história gira em torno da construção de casas coletivas, cuja propriedade é do português João Romão, personagem central do romance. O português acumula dinheiro e compra um estabelecimento comercial com a ajuda de Bertoleza, escrava com quem acaba 'se 
juntando' e a quem concede a carta de alforria (que se revela falsa). Com o tempo, constroem a estalagem onde ocorre todo o enredo. Nela moram e convivem os mais variados tipos: brancos, negros, mestiços, estrangeiros. Percebe-se a influência do meio social em Azevedo, ao construir seres fictícios marcados, como a figura da mulata sensual e promíscua (Rita Baiana), do malandro carioca (Firmo), dos libertos estigmatizados pela escravidão (Bertoleza) e do estrangeiro que, mesmo sendo pobre ou em via de ascensão e trabalhador como os demais moradores do cortiço, é europeu, logo superior (Jerônimo e Romão).

É notável a capacidade do autor em abordar os agrupamentos e tipos humanos. Suas personagens derivam da vida cotidiana, popular e marginalizada: a lavadeira, o feirante, o operário, a prostituta, o malandro, o ex-escravo. O lugar pintado no romance é marcado pela sujeira, insalubridade, miséria, por habitações precárias, pelo odor forte, pela doença e ausência de políticas públicas. Em suma, o cortiço simboliza um espaço de corrupção e contágios - de moléstias como febre amarela, tuberculose e varíola e dos próprios vícios que eram atrelados à herança biológica, como o alcoolismo e a prostituição.

O que se observa, no decorrer da narrativa, é a exploração do homem pelo homem, a luta pela sobrevivência, a vitória dos mais aptos, em conformidade com os preceitos evolucionistas da época, a exemplo do determinismo geográfico. As personagens são apresentadas como seres instintivos, a reagir ao clima do lugar e biologicamente ao seu sangue racial, características que se encontram igualmente nas personagens de Aranha. À medida que os indivíduos cedem aos prazeres da terra vão-se corrompendo, naturalizando-se ou animalizando-se. Essa imagem de 'degenerescência' pode ser notada no português e cavouqueiro Jerônimo, ao ser seduzido pela mulata Rita Baiana. O processo de transformação da personagem é claro. Jerônimo, desenhado com "pescoço de touro e cara de Hércules" e como homem sério e honesto, aos poucos vai-se "abrasileirando", amolecendo-se, tornando-se preguiçoso, esbanjador, distraído, adquirindo desejos, "resignando-se, vencido, às imposições do sol e do calor ..." (Azevedo, 1999, p.87).

É significativo o papel que Rita Baiana desempenha na mudança de Jerônimo. Ao vê-la dançando, numa roda de pagode, o português fica entorpecido e apaixonado, dando início à alteração de seu caráter e de seu corpo. Troca o vinho pela aguardente, o bacalhau pela carne-seca e o feijão-preto; aprende a fumar, apura os sentidos e aos poucos emagrece (Azevedo, 1999, p.36). O feitiço praticado por Rita é análogo àquele exercido pela própria terra. A mulata mimetiza, com o sangue mestiço, o sol, o clima e toda a atração que esses elementos provocam nos homens. Isso é perceptível pela forma como a personagem é composta no romance, comparada aos elementos e mistérios da natureza: "ela era a luz ardente do meio-dia", "a palmeira virginal", "a castanha do caju", "a cobra verde e traiçoeira, a lagarta viscosa, a muriçoca doida, que esvoaçava havia muito tempo em torno do corpo dele, assanhando-lhe os desejos ..." (p.73).

Enquanto Jerônimo cai na desordem, a personagem Romão, também português, em procedimento inverso, caminha para a ordem. Um metaforiza o estrangeiro que cedeu à injunção da terra; outro simboliza o estrangeiro que vem para dominá-la. Destarte, Romão, traçado como velhaco e ladrão, sofrendo todos os tipos de privações, sempre "em mangas de camisa", de "tamancos", "sem meias" e a "barba por fazer", pouco a pouco torna-se um novo indivíduo: "Mandou fazer boas roupas e aos domingos refestelava-se de casaco branco 
e de meias, assentado defronte da venda, a ler jornais. Depois deu para sair a passeio, vestido de casimira, calçado e de gravata. Deixou de tosquiar o cabelo à escovinha; pôs a barba abaixo, conservando apenas o bigode ..." (Azevedo, 1999, p.133).

O que acontece no plano social também se passa no plano da natureza. Nota-se como o ambiente brasileiro atua energicamente sobre a atmosfera europeia: "Assim à refulgente luz dos trópicos amortece a fresca e doce claridade dos céus da Europa, como se o próprio sol americano, vermelho e esbraseado, viesse, na sua luxúria de sultão, beber a lágrima medrosa da decaída rainha dos mares velhos" (Azevedo, 1999, p.73). A natureza brasileira é a figura mais poderosa no romance, sendo apontada por Piedade, mulher de Jerônimo, como a determinante na mudança do marido, pelo narrador, como motivo da briga entre o cortiço de Romão e o Cabeça de Gato, e também assinalada como agente da puberdade em Pombinha.

$O$ cortiço é parte integrante desse ambiente tropical constantemente assemelhado a uma grande floresta, a um formigueiro ou a uma serpente: "E naquela umidade quente e lodosa, começou a minhocar, a esfervilhar, a crescer, um mundo, uma coisa viva, uma geração, que parecia brotar espontânea, ali mesmo, daquele lameiro, e multiplicar-se como larvas no esterco" (Azevedo, 1999, p.26). Antes de tudo, a estalagem era um organismo vivo, autônomo, sem uma lei regente, a não ser a imanente ao clima e ao sangue. Em razão disso, a narração do cortiço se apresenta, em um primeiro nível, de forma genérica, sem identificações. São apenas "machos e fêmeas", "cabeças congestionadas de sono", risos e vozes que se mesclam e se dissolvem no "grande formigueiro". O efeito é obtido por meio do uso da terceira pessoa, quase sempre no plural, a indeterminar os habitantes do lugar:

Entretanto, das portas surgiam cabeças congestionadas de sono; ouviam-se amplos bocejos, fortes como o marulhar das ondas; pigarreava-se grosso por toda parte; começavam as xícaras a tilintar; o cheiro quente do café aquecia, suplantando todos os outros; trocavamse de janela para janela as primeiras palavras, os bons-dias; reatavam-se conversas interrompidas à noite ... No confuso rumor que se formava, destacavam-se risos, sons de vozes que altercavam, sem se saber onde ... (p.35; grifos nossos).

Somente após essa exposição geral é apresentada uma gama de personagens, em sua maioria lavadeiras: a portuguesa Leandra e seus três filhos - das Dores, Nenen e Agostinho; Augusta Carne-Mole, brasileira e branca; o mulato e policial Alexandre; Leocádia, também de origem lusitana; Paula, cabocla velha e feiticeira; a mulata Marciana e sua filha Florinda; a velha Isabel e sua enfermiça filha Pombinha; Albino, moço fraco e afeminado. Enfim, gira em torno dessas figuras um mundo de miséria, promiscuidades, adultérios, doenças, assassinos, impulso sexual e imundícies, a contaminar tudo e todos.

A imagem do cortiço como contágio de vícios e moléstias é reproduzida, pois na época a ficção mostrava esse tipo de moradia como espaço de corrupção moral. Logo, Pombinha, moça recatada, vira prostituta e induz a filha de Jerônimo ao meretrício: "A cadeia continuava e continuaria interminavelmente; o cortiço estava preparando uma nova prostituta naquela pobre menina desamparada ..." (Azevedo, 1999, p.201). Como recinto de sujeira, a estalagem estava atrelada à infecção, em especial da febre amarela: “- Quero isto limpo! bramava furioso. Está pior que um chiqueiro de porcos! Apre! Tomara que a febre amarela os lamba a todos! Maldita raça de carcamano ..." (p.106). Aqui, o imaginário recria um 
discurso bastante comum na sociedade brasileira: os alojamentos coletivos são imundos, sem nenhuma condição sanitária e abrigam toda sorte de delinquentes.

Entretanto, se por um lado a obra azevediana trata de um problema social específico, por outro engloba o país inteiro. Para Cândido (1991, p.119), o cortiço seria uma alegoria do Brasil, "com a sua mistura de raças, o choque entre elas, a natureza fascinadora e difícil, o capitalista estrangeiro postado na entrada, vigiando, extorquindo, mandando, desprezando e participando". Não obstante, para além dos elementos nacionais impressos no romance, é relevante saber quais respostas ou solução a ficção abona, com respeito ao Brasil. Nesse sentido, a trajetória de Romão e de sua estalagem é elucidativa. E não é apenas o dono do cortiço que passa por uma transformação; sua propriedade também é reformada. Depois do incêndio que destruiu 35 casas, provocado pela cabocla Paula, as residências coletivas ganharam novos ares, e não mais se aceitou gente ociosa e suja: "Já lá se não admitia assim qualquer pé-rapado: para entrar era preciso carta de fiança e uma recomendação especial. Os preços dos cômodos subiam, e muitos dos antigos hóspedes, italianos principalmente, iam, por economia, desertando para o Cabeça de Gato e sendo substituídos por gente mais limpa ..." (Azevedo, 1999, p.198).

A mudança por que passam Romão e seu cortiço é paralela às mudanças sentidas no país. Conforme mencionado, o Brasil, para se fazer moderno e civilizado, tornava-se um viveiro de obras, alterava a sua estrutura urbana, adquiria novos hábitos, rejeitando o seu passado colonial e imperial. A nação, reclamando uma higienização mental e corporal, afastava para os arrabaldes e morros as classes pobres. O mesmo ocorria no universo ficcional de Azevedo (1999). O português avarento se adapta aos novos tempos, modernizando-se. Romão não somente atualizava seus negócios e suas indumentárias, mas também negava seu passado - constantemente lembrado pela negra Bertoleza, a imagem viva do que ele fora. A escrava era vergonha que precisava ser eliminada, e por isso foi entregue a seus antigos donos. A escravidão era, do mesmo modo, a recordação ruim que manchava e embaraçava a jovem República brasileira. É expressiva a cena final do livro, pois remete não só à 'sinuosidade' do dono da estalagem - que ora agia como um escravocrata do Império, ora se comportava como um liberal da República -, mas também à volubilidade do país. Ironicamente, na ocasião em que a escrava é devolvida, surge um grupo de abolicionistas para diplomar o lusitano: "nesse momento para à porta da rua uma carruagem. Era uma comissão de abolicionistas que vinha, de casaca, trazer-lhe respeitosamente o diploma de sócio benemérito" (Azevedo, 1999, p.207).

Em suma, a história de Romão e do cortiço mimetiza o advento de um novo tempo, marcado pelo ganho fácil, pela especulação, pela ideia de limpeza e de bom gosto. Há, na narrativa, duas temporalidades: uma que se quer esquecida, uma vez que é feia e promíscua, e outra que se organiza, higieniza-se, vê no futuro um horizonte de riqueza e sofisticação. Nesse caso, o português simboliza a vitória do arrivista que adere às necessidades atuais, a fim de não ser engolido por elas. Por outro lado, o que não se ajusta à nova situação é alvo do Estado e de sua instituição máxima, a polícia. É o que acontece com o Cabeça de Gato: "estava vencido finalmente, vencido para sempre; nem já ninguém se animava a comparar as duas estalagens. À medida que a de Romão prosperava daquele modo, a outra decaía de 
todo; raro era o dia em que a polícia não entrava lá e baldeava tudo aquilo a espadeira de cego. Uma desmoralização completa!" (p.202). Ou ainda:

E a mísera (Piedade), sem chorar, foi refugiar-se, junto com a filha, no "Cabeça de Gato" que, à proporção que o São Romão se engrandecia, mais e mais ia-se rebaixando acanalhado, fazendo-se cada vez mais torpe, mais abjeto, mais cortiço, vivendo satisfeito do lixo e da salsugem que o outro rejeitava, como se todo o seu ideal fosse conservar inalterável, para sempre, o verdadeiro tipo de estalagem fluminense, a legítima, a legendária; aquela em que há um samba e um rolo por noite; aquela em que se matam homens sem a polícia descobrir os assassinos; viveiro de larvas sensuais em que irmãos dormem misturados com as irmãs na mesma lama; paraíso de vermes, brejo de lodo quente e fumegante, donde brota a vida brutalmente, como de uma podridão (p.202; grifos nossos).

Enquanto a estalagem São Romão, agora avenida, amoldava-se às exigências do presente, o Cabeça de Gato caía em um plano temporal mitológico, inalterado. Seu destino era visível: a destruição. A esse respeito, cabe menção a Chalhoub (1996, p.17), sobre o fim dos cortiços no Rio de Janeiro, em particular a demolição do Cabeça de Porco:

A destruição da Cabeça de Porco marcou o início do fim de uma era, pois dramatizou, como nenhum outro evento, o processo em andamento de erradicação dos cortiços cariocas. Nos dias que se seguiram, o prefeito da Capital Federal foi calorosamente aclamado pela imprensa - ao varrer do mapa aquela "sujeira", ele havia prestado à cidade "serviço inolvidáveis". Com efeito, trata-se de algo inesquecível: nem bem se anunciava o fim da era dos cortiços, e a cidade do Rio já entrava nos séculos das favelas.

A esta altura, convém observar o romance $O$ cortiço sob a ótica do discurso escravista, da situação dos mestiços e de sua necessidade de se tornarem brancos. Do mesmo modo que Azevedo faz de sua obra instrumento de queixa social, também reforça a imagem, corrente na época, do Brasil e dos brasileiros. Assim, mesmo 'liberta', Bertoleza, inferiorizava-se e, por ter sido escrava e ser negra, não se achava no direito de protestar por uma vida melhor, mantendo-se submissa, escrava e dependente de Romão. E apesar de saber que o marido, a quem dedicou a vida e ajudou a enriquecer, queria dela se desvencilhar para casar-se com outra, permanecia muda. Bertoleza é a representação de uma realidade nacional, a expressão da ideia de que a união do branco com o negro seria uma alternativa para a melhoria da raça. Quem era a personagem senão "a mancha negra", "a indecorosa nódoa", o mestiço, que no nível do sentimento nacional, impedia o progresso e o desenvolvimento do país? Mesmo liberta Bertoleza ainda continuava escrava, não só porque "era a primeira a erguerse e a última a deitar-se", mas também porque o preconceito dos brancos (Dona Estela, Miranda, Romão) estava presente em sua vida. Uma vez identificada como animal inferior e repugnante, a solução para ela era 'purificar-se' com uma raça superior, a branca.

Para boa parte dos intelectuais da época, negros e brancos eram espécies humanas distintas 5 , o que era motivo para impedir que eles se relacionassem e procriassem. A mestiçagem era ato condenatório, vista como um mal em potencial que precisava ser controlado pelo bem da humanidade.

A mistura racial foi tema frequente no pensamento brasileiro da virada do século XIX para o XX. Para estudiosos brasileiros de então, era urgente explicar que país era este e qual o caminho a seguir, diante de prognósticos tão negativos em relação a nós. Era preciso 
enfrentar essas teorias e o conceito de raça. Admitir que a raça determinava o futuro de uma nação e que negros, índios e mestiços eram inferiores significava aceitar, de antemão, a impossibilidade de desenvolvimento do país. Isso explica a angústia desses intelectuais responsáveis por responder sobre a nação e seus problemas, o dilema ao aceitar os modelos deterministas para pensar o país. Assume-se, então, a inferioridade de negros e indígenas, mas 'negocia-se' a degeneração dos mestiços. Ora ela é considerada inevitável (Rodrigues, 2008), ora brada-se sua conversão ao tipo branco por meio da miscigenação (controlada) com pessoas de pele mais clara (Lacerda, 2011). Já que não era possível eliminar a mistura indesejada, propunham-se meios de amenizá-la, a exemplo do processo de 'branqueamento'.

A teoria do branqueamento trazia consigo uma ambiguidade curiosa: ao mesmo tempo que considerava a mestiçagem um mal a ser impedido, via-a como possibilidade de salvação (Seyferth, s.d.). Os mestiços eram uma realidade. Como resolver um problema posto? Branqueando as gerações subsequentes desses indivíduos. Nesse sentido, a imigração europeia, com preferência por alemães e italianos, favoreceria a aceleração desse processo. Vale ressaltar que, na política do branqueamento, a mestiçagem incentivada era uma mestiçagem controlada e direcionada, ou seja, os indivíduos deveriam procurar, sempre, pessoas de cor mais clara, se não brancas, para se relacionarem. Entre os defensores do branqueamento destacou-se o diretor do Museu Nacional João Batista de Lacerda, que apontava um Brasil branco em um século. Sua iniciativa foi criticada por alguns de seus pares, como Sílvio Romero, por ser muito otimista; outros o criticavam por ser o prazo de cem anos muito longo. Lacerda representou o Brasil no Primeiro Congresso Universal das Raças, em 1911, em Londres. O Brasil foi o único país da América Latina presente no Congresso, fato que demonstra a preocupação nacional com o assunto.

No Brasil do século XIX, portanto, a panaceia para o problema racial, defendida por muitos médicos adeptos da eugenia, foi o incentivo ao casamento entre brancos e mestiços, o estímulo à queda de fertilidade dos africanos e a vinda de imigrantes. A urgência em transformar o país em uma nação branca inquietava os brasileiros, que, tendo conhecimento de sua mistura racial, tinham que encontrar formas de branquear sua descendência para serem aceitos pela sociedade, também mestiça.

"Ele (Romão) propôs-lhe morarem juntos, e ela concordou de braços abertos, feliz em meter-se de novo com um português, porque, como toda cafuza, Bertoleza não queria sujeitar-se a negros e procurava instintivamente o homem numa raça superior a sua" (Azevedo, 1999, p.16). Rita Baiana também vê no sangue europeu uma forma de ascender socialmente. Mesmo que o casamento não a branqueie e não afiance a ascensão financeira, ele traz a possibilidade de filhos mais brancos, no futuro: "mas desde que Jerônimo propendeu para ela, fascinando-a com a sua tranquila seriedade de animal forte e bom, o sangue da mestiça reclamou os seus direitos de apuração, e Rita preferiu no europeu o macho da raça superior ..." (p.151).

Percebe-se como o discurso do branqueamento atingiu a sociedade como um todo. Com todos os problemas de uma cultura dependente, 'aceitar', ou pelo menos considerar as doutrinas raciais, era uma 'aproximação' com a ciência da época. Negá-las significava dizer não ao progresso, à civilização; acolhê-las, negar o Brasil como nação e os brasileiros como povo. Daí as inquietações e contradições de nossos intelectuais e governantes, ao 
tratar do futuro do país. Com vários discursos e influências teóricas, esses homens procuravam definir o país. Tarefa complexa; afinal, como congregar nossa pluralidade étnica e cultural numa só nação? Pensar a construção da nacionalidade e de uma identidade era, sobretudo, conciliar o que se apresentava inconciliável.

O branqueamento está presente também em Canaã (Aranha, 2006), porém apresentado como horizonte futuro para o projeto civilizatório brasileiro. O estado do Espírito Santo, mais precisamente a cidade de Porto do Cachoeiro, é o cenário narrativo. A obra abarca temas complexos como a situação dos libertos da escravidão, a ideia de inferioridade do mestiço e, sobretudo, a imigração e a política racial. Embora Aranha tenha escolhido uma cidade interiorana do Espírito Santo, distanciando-se da atmosfera requintada da belle époque carioca, sua trama não está destituída da

mesma ânsia de modernização ... e o mesmo empenho em liquidar a herança colonial que nos entravava o progresso ... Só que, contrariamente à empresa de cosmetização da realidade brasileira a que se aplicou a belle époque a fim de legitimar o novo regime republicano aos olhos ainda desconfiados da Europa e dos Estados Unidos, havia no romance de estreia de Graça Aranha uma 'rara consciência crítica dos problemas raciais, sociais e morais do povo brasileiro', como dele disse bem Alfredo Bosi (Paes, 1992, p.17).

Identificado como um romance de ideias, que se contrapõem nos diálogos entre Milkau e Lentz, personagens centrais da trama, a história aborda as angústias da virada do século no Brasil, com todo o peso das ideologias cientificistas proeminentemente contrárias à miscigenação e à possibilidade de desenvolvimento de um país tropical. A influência de Tobias Barreto e da escola de Recife sobre Aranha se faz sentir no enredo. Raça e natureza, entraves ao progresso nacional, numa perspectiva mais ampla, são referências constantes, ora condenadas, nas falas de Lentz, ora saudadas ou pontuadas por Milkau. Tal oscilação é representativa de um momento de profundas mudanças estruturais no país, acompanhadas pelas aflições da 'elite pensante', dos governantes e também do povo, a parte mais prejudicada.

Vale sublinhar que o contraste de pensamento entre os dois amigos é transposto para seus traços físicos. Milkau é esboçado "com uma pele rósea e branda de mulher", ao passo que Lentz se figura como um jovem cuja linha do rosto é acentuada e forte. Dessa forma, o primeiro é um romântico, um idealista que vem para o Brasil em busca de uma vida estável e livre, que coincida com as aspirações existenciais de seu caráter. Com base numa explicação niveladora e amorfa do mundo, ele acredita que "as raças civilizam-se pela fusão", cabendo aos "povos superiores" o impulso para "o desdobramento da cultura". Já o segundo, arrebatado por uma mentalidade predadora, com tintas nietzschianas, tem total descrença no brasileiro (mestiço) como agente civilizador e vê no imperialismo alemão a única alternativa para desenvolver o Brasil. Todas as suas falas são de negação do nativo, como povo e como elemento de progresso.

As discussões dos alemães gravitam em torno de o brasileiro ser ou não capaz de 'fazer' o país e, mormente, que papel pode exercer o imigrante nessa tarefa. É relevante notar o título dado ao romance. Em alusão à Bíblia, Canaã é a terra prometida, por Deus a Abraão. Nela, a divindade prenuncia um tempo de benção e a formação de uma grande nação, 
fundada sob amor, harmonia e paz (Gênesis 12, 1, 2, 3). É baseada nessa imagem vindoura que a obra pensa o Brasil. Nossa altivez nacional é remetida para o futuro. Quais elementos são evidenciados, na ficção, como fatores que impedem o desenvolvimento do país? Como eles são esteticamente elaborados?

Um primeiro obstáculo ao desenvolvimento seria a natureza, ao mesmo tempo grandiosa e hipnótica, violenta e acolhedora. Destaca-se, no romance, o sol esbraseado, incômodo, que "queimava o sangue" e "inflamava as coisas". Contudo, em Canaã o astro não tem a mesma força mostrada n'O cortiço, porque é suavizado pelo "ar leve", pelas sombras benfazejas e pelo perfume voluptuoso das florestas. Essa incongruência da selva brasileira pode ser acompanhada com a personagem Maria Perutz, imigrante pobre, órfã e abandonada pelos patrões quando estava grávida. Uma vez sozinha na mata escura, ela é agasalhada por vaga-lumes, que a cobrem como um manto sagrado: "Depois de os vaga-lumes incontáveis cobrirem-na, os andrajos desapareceram numa profusão infinita de pedrarias, e a desgraçada, vestida de pirilampos, dormindo imperturbável, como tocada de uma morte divina, parecia partir para uma festa fantástica no céu, para um noivado com Deus..." (Aranha, 2006, p.136). Mas essa mesma natureza atua sobre a personagem de maneira brutal, devorando seu filho recém-nascido, que é estraçalhado e partilhado por uma manada de porcos: "Os porcos, sentindo-a sossegada, precipitaram-se sobre os resíduos sangrentos, espalhados no chão. Devoram tudo, sôfregos, tremendos; sorveram o sangue e na excitação da voracidade arremessaram-se à criança, que às primeiras dentadas soltou um grito forte ..." (p.160). Essa oscilação do ambiente brasileiro cria a sensação de um espaço secreto, ainda a se conquistar, e levanta dúvidas sobre a idoneidade de uma civilização erguida nos trópicos. Em face disso, a narrativa se mostra lenta, suspensa pelos constantes diálogos, pelas descrições da paisagem, pelas lendas dos nativos e dos imigrantes e pela história sofrida de Maria. Em outras palavras, esse enredo entrecortado e tecido sobre uma natureza selvagem é a representação artística de um Brasil que se percebia como embrionário. No centro da narrativa, um dilema fundamental: o de ser uma nação.

Um segundo entrave ao progresso nacional seria o mestiço. No romance ele é conectado ao panorama das matas brasileiras e caracteriza-se pelo primitivo, pela sedução, espontaneidade, alegria, bondade e indolência. Três mulatos podem ser enfatizadas: o agrimensor Felicíssimo, que, conforme o nome acusa, é um rapaz alegre e de atitudes exageradas; Joca, moço ingênuo e melancólico que, vindo do Maranhão, se sente em terra estrangeira, cercada por imigrantes alemães; e o escrivão Pantoja, homem inescrupuloso, que usa a justiça com fins lucrativos e sórdidos. Quanto a este último personagem, é significativo o nome que lhe foi dado pelo autor: o prefixo grego panto, que o compõe, expressa a ideia de 'tudo', 'todos', uma clara insinuação de que o mestiço, em seu tipo mais corrupto, era quem governava o país. Isso pode ser observado na conversa entre o juiz municipal Maciel e Milkau:

- Vejo bem que é isso mesmo, comentou o juiz. Era preciso formar-se do conflito de nossas espécies humanas um tipo de mestiço, que se conformando melhor com a natureza, com o ambiente físico, e sendo a expressão das qualidades médias de todos, fosse o vencedor e eliminasse os extremos geradores. Perfeito... Reparemos que Pantoja não é um caso isolado. Os que tendem a nos governar, e que nos governam com melhor aceitação e êxito, são desse mesmo tipo de mulatos. O Brasil é, enfim, deles... (Aranha, 2006, p.178). 
O insucesso desse governo dirigido por 'raças inferiores' é registrado em uma cena de Felicíssimo com o teodolito. Trava-se uma 'luta' entre a personagem e o aparelho de medição, que termina com a derrota do agrimensor. A passagem é hilária mas carregada de simbologia, pois mimetiza a incapacidade de o mestiço ser instrumento de modernização:

O agrimensor calou-se ainda mais solene e entregou-se todo ao instrumento; mirava na objetiva, abaixava-se, erguia-se para espiar por cima, voltava a retificar as lentes, torcendoas ora demais, ora de menos, sempre com insucesso. Já o tomava a angústia de não acertar, mas ora teimava em seus movimentos, ora abandonava o aparelho e ia mirá-lo de longe. Voltava ao instrumento, tornava a ajeitá-lo, espiava outra vez e sempre o mesmo resultado negativo ... (Aranha, 2006, p.75).

Percebe-se que tanto Pantoja quanto Felicíssimo encarnam predicados negativos da mistura racial. Um alude a um ser corrompido e viciado; outro, à inépcia do nativo para o mundo civilizado. Já no caso de Joca, a representação do mestiço se concentra na sedução e no frenesi da terra, e assim como a Rita Baiana d'O cortiço, o mulato é a metáfora da natureza, sendo traçado como um caçador com dentes serrados, iguais aos de um felino. Os livros de Azevedo e Aranha trocam diálogo íntimo por meio dessas duas personagens: a dança convulsa da mulata que encantava o português Jerônimo responde ao requebrado de Joca, que, em meio ao frígido sangue alemão, não seduzia ninguém.

Verifica-se ainda, comparando-se as duas obras, o pensamento racial acerca da vitalidade dos europeus. O bamboleado de Rita atrai o português, cuja aptidão sexual, em detrimento de outras 'raças europeias', foi defendida por estudiosos como Gilberto Freyre e Sérgio Buarque de Holanda. Já o malogro de Joca resulta da frieza carnal dos germânicos, que pode ser confirmada pela castidade de Milkau e por sua angústia ao sentir atraído por Maria Perutz.

Retomando o problema nacional em Aranha, compreende-se, então, por que o Brasil, como nação, é lançado para o futuro, cuja solução apresenta-se, na obra, pela política do branqueamento. Milkau profetiza a Canaã de seus sonhos, onde "a época dos mulatos passará", dando origem a um novo mestiço que seriam os "novos brancos", procedentes da fusão e do amor entre as raças. Segundo Martins (2010), muito dos romances brasileiros de caráter patriótico são tecidos com histórias de amor entre nativos e estrangeiros, configurando uma composição que remete a uma 'identidade nacional'. São exemplos disso Iracema, de José de Alencar, e o próprio $O$ cortiço, de Azevedo.

A obra de Aranha também é perpassada pelo imaginário amoroso, mas, diferentemente dos livros citados, o amor não é consumado pela união carnal entre mestiço e europeu. O laço afetivo fica por conta da utopia racial de Milkau, que acredita que só o amor pode conduzir e unir os homens. Vale ressaltar que até mesmo esse sentimento é projetado num devir, uma vez que a violência sofrida por Maria, condenada como infanticida tal qual a Margarida do Fausto goethiano, descortina, para Milkau, a ferocidade da própria terra e dos indivíduos. A esperança de unidade, no entanto, é metaforizada pelos cantos conjuntos de brasileiros e alemães, na cena que discorre sobre o teodolito; e pela festa patrocinada por Jacob Müller, quando se acoplam as raças 'superiores' e 'inferiores', sem distinção de classe ou idade. Destarte, para o protagonista somente o amor advindo do sofrimento cimenta e torna possível uma civilização. 
Milkau sente-se responsável pela aquela gente 'primitiva', em resolver seus problemas e dilemas. A fusão das raças e o amor poderiam alicerçar uma nova civilização brasileira, representada na imagem do mestiço de tez clara. No mais, as inquietações de Milkau e Lentz refletem, com as singularidades próprias da literatura, a realidade nacional que Aranha testemunhou. A esse respeito, Paes (1992, p.65-65) sintetizou: "No fundo, o que os dois incansáveis interlocutores de Canaã fazem é exprimir as perplexidades de um mesmo fim de século em que a razão científica começava a duvidar de suas certezas e o modelo biológico de explicação, a tropeçar em suas próprias armadilhas".

\section{Considerações finais}

No Brasil, a guinada do século XIX para o XX foi marcada, como toda transição, por uma irrupção de ideias e conflitos, permeada de aspectos científicos, tecnológicos e ideológicos. No cerne desse momento histórico estavam as teorias raciais, que buscavam compreender o país e suas mazelas sociais por meio de explicações biológicas. A maioria dos intelectuais da época foi inábil em perceber que os problemas brasileiros eram consequências da estrutura econômica e política da nação e não de nossa mestiçagem, vista então como força motora de nossa 'inferioridade' e 'indolência'.

O universo ficcional do período também trouxe, nas entrelinhas do imaginário, a sociedade que o motivou, servindo de testemunho histórico. Na literatura, as tensões nacionais e o discurso da ciência estão presentes em metáforas, anedotas e personagens que representam um 'verdadeiro' retrato do país. Esse aspecto não é exclusivo das obras aqui analisadas, $O$ cortiço e Canaã; ele perpassa a mentalidade daquele tempo, que é pensado tanto pelo modo sociológico quanto pela ficção. Um exemplo é a obra de Machado de Assis, que pensa o Brasil e as teorias científicas (darwinismo social, positivismo, entre outras) por meio de narizes e borboletas (Chalhoub, 2003).

Os livros aqui abordados são não apenas uma invenção da mente de seus autores, mas também uma criação historicizada, cuja matéria-prima são as atitudes e representações sociais e culturais de um tempo. Portanto, pode ser proveitoso observar o que, na ficção, não é ficção. A propósito, nota-se, tanto n'O cortiço quanto em Canaã, um determinismo geográfico que é manifestado na personificação da natureza, que ameaça, embriaga e seduz os homens. Essa 'linha direta' da ficção com a natureza se dá ao mesmo tempo que a paisagem é estereotipada, resultando afinal relativamente inócua sua participação (Süssekind, 2000, p.33). As teorias raciais são também esquematizadas em personagens mestiças e suas relações com os europeus, sendo o brasileiro assinalado por alusões a preguiça, volúpia, ações instintivas ou bondade e ingenuidade. Tais percepções são constantes na representação ficcional brasileira, nos tempos vindouros (Leite, 2002), e embasam em parte, até hoje, preconceitos das classes mais abastadas com relação aos nordestinos, caipiras e caiçaras, ou negros e mulatos. Percebe-se igualmente o mestiço como um ser incapacitado para promoção da modernidade nacional, cabendo ao estrangeiro (Romão ou Milkau) o papel de mola propulsora do país. Em todas essas atribuições de papéis conforme o tipo racial, apelava-se para a autoridade da ciência, ou melhor, dos que se pretendiam conhecedores de ciências da época, fossem as teorias antropológicas ou da 
eugenia - enfim, para um cientificismo erigido, em geral, com base pouco científica sob ralas camadas de verniz, mas habilidoso em atribuir a si o estatuto de verdade e atrair o interesse das camadas letradas do país. E certamente os componentes de positivismo, evolucionismo e materialismo, que envolviam esse cientificismo, eram de molde a convencer os que ansiavam por modernidade num país de atrasos em tantos setores.

Os romances ainda oferecem duas soluções para o Brasil. O cortiço, numa visão mais negativa, vê na vitória do branco português o domínio da nação e seu destino - e a figura de Romão é, nesse sentido, estratégica. Já em Canaã vemos a síntese racial, impulsionada pelo branqueamento, dar origem a um novo mestiço, capaz de engendrar o desenvolvimento do país. Qual das duas opções era mais interessante e condizente com o desenvolvimento histórico da nação foi (e continua sendo) tema de muitas obras de ficção e ensaios.

Por fim, também procurou-se mostrar, com este estudo, que a literatura pode ser fonte legítima e enriquecedora para a investigação histórica, uma vez que o imaginário aprofunda e toca a vida íntima de uma sociedade, ora recriando e reforçando certos tipos de práticas e símbolos sociais, ora contestando e debatendo as estruturas do poder.

\section{NOTAS}

${ }^{1}$ Uma boa análise sobre a ligação do movimento pangermanista e daquele que o encampou, o nazismo, com a mística da terra, representada pelas florestas nativas do norte europeu, encontra-se em Schama, 1996.

${ }^{2}$ Sobre a postura dos intelectuais brasileiros diante das teorias raciais, ver Schwarcz, 2002, Munanga, 2006 e Ortiz, 2006.

${ }^{3}$ Sobre o tráfico de escravos, ver, entre outros, Alencastro, 2006.

${ }^{4} \mathrm{O}$ fundador do naturalismo, Émile Zola, foi também quem melhor expressou literariamente a crença nas explicações cientificistas do desequilíbrio social e individual em decorrência do determinismo biológico, a exemplo de seu romance Germinal (Gaillard, 1994).

${ }^{5}$ Em direção oposta aos monogenistas, que acreditavam em uma origem única da humanidade a partir de Adão e Eva, os poligenistas criam que a origem dos homens era diversa, o que explicava as diferentes raças. Ora, sendo brancos e negros de espécies distintas, o cruzamento entre eles resultaria num ser infértil, o que não se observa. Este foi um problema maior para os teóricos racistas, uma vez que a fecundidade dos mestiços aumentava a população dessa sub-raça, conforme a classificavam tantos estudiosos.

\section{REFERÊNCIAS}

ALENCASTRO, Luiz Felipe de.

O trato dos viventes: formação do Brasil no Atlântico sul. São Paulo: Companhia das Letras. 2006.

ARANHA, Graça.

Canaã. São Paulo: Ática. 2006.

AZEVEDO, Aluísio de.

O cortiço. São Paulo: Ática. 1999.

BOSI, Alfredo.

História concisa da literatura brasileira. São Paulo: Cultrix. 2006.

CÂNDIDO, Antonio.

De cortiço a cortiço. Novos Estudos CEBRAP,
São Paulo, n.30, p.111-129. Disponível em: http://www.4shared.com/get/qtVxutfZ/ Antonio_Candido_-_De_cortio_a_.html. Acesso em: 17 jan. 2010. 1991.

CARVALHO, José Murilo de. Os bestializados: o Rio de Janeiro e a República que não foi. São Paulo: Companhia das Letras. 1987.

CHALHOUB, Sidney. Machado de Assis: historiador. São Paulo: Companhia das Letras. 2003.

CHALHOUB, Sidney.

Cidade febril: cortiços e epidemias na corte 
imperial. São Paulo: Companhia das Letras. 1996.

GAILLARD, Françoise.

Genética e mito da gênese: a ciência do imaginário. In: Bessis, Henriette et al. A ciência e o imaginário. Brasília: Editora UnB. p.53-78. 1994.

GÊNESIS.

In: Bíblia sagrada. Trad., João Ferreira de Almeida. São Paulo: Sociedade Bíblica do Brasil, 1993.

HERMAN JR., Arthur.

A idéia de decadência na história ocidental. Rio de Janeiro: Record. 1999.

LACERDA, João Batista de.

Sobre os mestiços no Brasil. História, Ciências, Saúde - Manguinhos, Rio de Janeiro, v.18, n.1, p.234-242. Trabalho apresentado com o título "Sur le métis au Brésil", no Primeiro Congresso Universal das Raças, Paris, em 1911. 2011.

LEITE, Dante Moreira.

O caráter nacional brasileiro. São Paulo: Unesp. 2002.

MARTINS, Ana Claudia.

Não há pecado ao sul do Equador: história de amor construindo o Brasil. Revista Crítica de História, Maceió, ano 1, n.1, p.171-191. Disponível em: http://www.revista.ufal.br/ criticahistorica/attachments/article/56/ Nao\%20ha\%20Pecado\%20ao\%20Sul\%20 do\%20Equador.pdf. Acesso em: 9 fev. 2010. 2010.

MUNANGA, Kabengele.

Rediscutindo a mestiçagem no Brasil: identidade nacional versus identidade negra. Belo Horizonte: Autêntica. 2006.

NEEDELL, Jeffrey D.

Belle époque tropical: sociedade e cultura de elite no Rio de Janeiro na virada do século. Trad., Celso Nogueira. São Paulo: Companhia das Letras. 1993.

ORTIZ, Renato.

Cultura brasileira e identidade nacional. São Paulo: Brasiliense. 2006.
PAES, José Paulo.

Canaã e o ideário modernista. São Paulo: Editora da Universidade de São Paulo. 1992.

PERRONE-MOISÉS, Leyla.

Flores da escrivaninha: ensaios. São Paulo: Companhia das Letras. 1990.

RAEDERS, Georges.

O inimigo cordial do Brasil. Rio de Janeiro: Paz e Terra. 1988.

RODRIGUES, Nina.

Mestiçagem, degenerescência e crime. História, Ciências, Saúde - Manguinhos, Rio de Janeiro, v.15, n.4, p.1151-1182. Artigo publicado originalmente em 1899, com o título

"Métissage, dégénerescence et crime", em Archives d'Anthropologie Criminelle, Lyon, v.14, n.83. 2008.

SCHAMA, Simon.

Paisagem e memória. São Paulo: Companhia das Letras. 1996.

SCHWARCZ, Lilia Moritz.

O espetáculo das raças: cientistas, instituições e questão racial no Brasil, 1870-1930. São Paulo: Companhia das Letras. 2002.

SEVCENKO, Nicolau.

Literatura como missão: tensões e criação cultural na Primeira República. São Paulo: Companhia das Letras. 2003.

\section{SEYFERTH, Giralda.}

João Batista de Lacerda: a antropologia física e a tese do branqueamento da raça no Brasil. Mimeo. s.d.

SÜSSEKIND, Flora.

O Brasil não é longe daqui: o narrador, a viagem. São Paulo: Companhia das Letras. 2000.

VELOSO, Mariza; MADEIRA, Angélica. Leituras brasileiras: itinerários no pensamento social e na literatura. São Paulo: Paz e Terra. 1999. 